\title{
PENGARUH RATIONAL EMOTIVE BEHAVIOR THERAPY TERHADAP KESEJAHTERAAN PSIKOLOGIS PENDERITA TB PARU DI UPTD PUSKESMAS PUHJARAK KEDIRI
}

\section{THE EFFECT OF EMOTIVE BEHAVIOR OF PSYCHOLOGICAL WELFARE OF LUNG TB PATIENTS IN UPTD PUSKESMAS PUHJARAK KEDIRI}

\author{
Nugrahaeni Firdausi ${ }^{1^{*}}$ \\ ${ }^{1}$ Sekolah Tinggi Ilmu Kesehatan Pamenang \\ *Korespondensi Penulis : nug_f@yahoo.co.id
}

\begin{abstract}
Abstrak
Pendahuluan: Sustainable Development Goals (SDGs) merupakan agenda pembangunan dunia yang bertujuan untuk kesejahteraan manusia dan planet bumi. Program END-TB adalah salah satu program yang dicanangkan oleh Sustainable Development Goals (SDGs). Pasien dengan TB Paru yang sedang menjalani terapi obat anti tuberkulosis dapat menimbulkan dampak bagi kesehatan fisik dan kesejahteraan psikologis yang merupakan salah satu domain dari kualitas hidup. Metode: Penelitian ini menggunakan desain penelitian quasy experiment dengan pendekatan pretest-posttest nonrandomized control group design. Teknik pengambilan sampel menggunakan purposive sampling. Sepuluh sampel yang didapatkan, di UPTD Puskesmas Puhjarak Kediri dibagi menjadi dua kelompok, 5 sampel kelompok perlakuan dan 5 sampel kelompok kontrol. Variabel independen dalam penelitian ini adalah kesejahteraan psikologis, dan variabel dependennya adalah Rational Emotive Behavior Therapy. Hasil: Hasil penelitian menunjukkan bahwa pada kelompok perlakuan di UPTD Puskesmas Puhjarak Kediri, terdapat peningkatan kesejahteraan psikologis pada saat pretest dan posttest. Nilai kesejahteraan psikologis kelompok perlakuan dan kontrol saat pretest menunjukkan $\mathrm{p}=1,000$. Nilai kesejahteraan psikologis kelompok perlakuan dan kontrol saat posttest menunjukkan $\mathrm{p}=0,050$. Pada kelompok perlakuan di UPTD Puskesmas Puhjarak Kediri terdapat peningkatan kesejahteraan psikologis setelah posttest, yaitu $\mathrm{p}=0,046$. Diskusi: Rational Emotive Behavior Therapy berpengaruh dalam meningkatkan kesejahteraan psikologis penderita TB Paru, namun nilai kesejahteraan psikologis dapat dipengaruhi oleh pendidikan dan status pekerjaan responden. Saran untuk penelitian selanjutnya diharapkan dapat melakukan pengendalian yang ketat pada lingkungan responden penelitian sehingga memberikan hasil yang maksimal.
\end{abstract}

Kata Kunci: Kesejahteraan Psikologis, Tb Paru, Rational Emotive Behavior Therapy

\begin{abstract}
Introduction: Sustainable Development Goals (SDGs) are a world development agenda aimed at the well-being of people and planet Earth. The END-TB Program is one of the programs launched by the Sustainable Development Goals (SDGs). Patients with pulmonary TB who are undergoing anti-tuberculosis drug therapy can have an impact on physical health and psychological well-being which is one of the domains of quality of life. Method: This study used a quasy experiment research design with a pretest-posttest nonrandomized control group design approach. The sampling technique uses purposive sampling. Ten samples obtained, at the UPTD Puskesmas Puhjarak Kediri were divided into two groups, 5 treatment group samples and 5 control group samples. The independent variable in this study is psychological well-being, and the dependent variable is Rational Emotive Behavior Therapy. Results: The results showed that in the treatment group at UPTD Puskesmas Puhjarak Kediri, there was an increase in psychological well-being at the pretest and posttest. The psychological well-being of the treatment and control group at the pretest showed $p=1,000$. The psychological well-being of the treatment and control group at the posttest showed $p=0.050$. In the treatment group at UPTD Puskesmas Puhjarak Kediriter there was an increase in psychological well-being after the posttest, which was $p=0.046$. Discussion: The Rational Emotive Behavior Therap has an effect on improving the psychological well-being of
\end{abstract}


patients with pulmonary $T B$, but the value of psychological well-being can be influenced by the education and employment status of the respondents. Suggestions for further research are expected to be able to exercise strict control on the research respondents' environment so as to provide maximum results.

Keywords: psychological well-being, pulmonary TB, Rational Emotive Behavior Therapy

\section{Pendahuluan}

Sustainable Development Goals (SDGs) merupakan agenda pembangunan dunia yang bertujuan untuk kesejahteraan manusia dan planet bumi. Sustainable Development Goals (SDGs) memiliki 17 tujuan dengan 169 target (18). Salah satu tujuan dari Sustainable Developmnet Goals (SDGs) adalah menjamin kehidupan yang sehat serta mendorong kesejahteraan hidup untuk seluruh masyarakat disegala usia (18). Sustainable Development Goals (SDGs) mencanangkan program ENDTB dan memiliki 3 indikator keberhasilan, yakni berkurangnya insidens TB paru di dunia sebanyak $80 \%$ pada tahun 2030 dibandingkan 2015, berkurangnya angka mortalitas sebanyak 90\% pada tahun 2030 dibandingkan tahun 2015, dan 0 (nol) biaya yang perlu dikeluarkan oleh penderita TB paru dalam rangka pengobatan penyakitnya (1).

TB paru adalah suatu penyakit infeksi yang disebabkan oleh mycobacterium tuberkulosis dan bersifat menular $(2,3)$. Kemenkes RI (4) menyebutkan beberapa faktor penyebab kasus TB paru terus meningkat, antara lain rendahnya kepatuhan minum obat yang sering disebabkan adanya efek samping obat. Pasien dengan TB Paru yang sedang menjalani terapi obat anti tuberkulosis dapat menimbulkan dampak bagi kesehatan fisik dan kesejahteraan psikologis yang merupakan salah satu domain dari kualitas hidup (22).

WHO menyatakan bahwa $1 / 3$ penduduk dunia telah terinfeksi kuman tuberculosis, sebanyak 9,6 juta kasus TB Paru di dunia dan 58\% kasus terjadi di daerah Asia Tenggara dan Afrika. Data WHO (5) menunjukkan bahwa Indonesia berada pada ranking kedua dengan beban TB tertinggi di dunia. Berdasarkan hasil survei, prevalensi TB paru tahun 2013, prevalensi TB paru smear positif per 100 ribu penduduk umur 15 tahun keatas sebesar 257. Provinsi Jawa Timur merupakan salah satu penyumbang jumlah penemuan penderita TB paru terbanyak kedua di bawah Provinsi Jawa Barat (5).
Data kota Kediri pada tahun 2015 menunjukkan bahwa penderita TB Paru sebanyak 167 orang. Jumlah keseluruhan kasus TB paru 273 kasus, BTA positif yang diobati sejumlah 140 orang $(83,83 \%)$, sedangkan angka kesembuhan untuk kasus TB BTA+ sebanyak 109 orang (77,86\%) (18). Pada tahun 2016 perkiraan penderita TB di kabupaten Kediri mencapai 1.656 orang (19). Pengambilan data awal di UPTD Puskesmas Puhjarak menunjukkan bahwa terdapat dua orang responden (20\%) dari sepuluh responden memiliki kesejahteraan psikologis yang kurang.

Penyakit TB paru disebabkan oleh mycobacterium tuberculosis yang menyebar melalui saluran limfe menuju kelenjar limfe regional. Penyebaran ini menyebabkan terjadinya inflamasi disaluran limfe (limfangitis) dan di kelenjar limfe (limfadenitis) yang terkena (6). Gejala TB paru dapat mengakibatkan demam, anoreksia malaise mual muntah, keletihan sehingga dampaknya bisa terjadi peningkatan suhu tubuh, perubahan nutrisi kurang dari kebutuhan dan intoleransi aktivitas(6). Penderita TB Paru akan mengalami perubahan pertama kalinya pada kesehatan fisik, apabila tidak ditangani akan menyebabkan masalah pada keadaan psikologisnya (7).

Penatalaksanaan TB paru selama ini masih menggunakan strategi DOTS dan salah satu komponennya adalah OAT yang harus dilaksanakan secara rutin selama 6 bulan dan tidak boleh putus dengan pengawasan langsung oleh Pengawas Minum Obat (PMO) (8). Penatalaksanaan pada pasien dan keluarga TB Paru selama ini masih berfokus pada fisik saja, padahal angka kesakitan pada penderita TB Paru juga bisa mempengaruhi kesejahteraan psikologisnya. Rational Emotive Behavior Therapy dipilih peneliti untuk meningkatkan kualitas hidup pada pasien TB Paru. Penelitian Santosa(2015) tentang Efektivitas Rational Emotive Behavior Therapy menunjukkan bahwa 90\% dapat menurunkan gejala gangguan psikologis 
(cognitive, affective, maupun somaticBehavioral). Rational Emotive Behavior Therapy menggunakan pendekatan konseling yang menekankan kebersamaan dan interaksi antara berpikir dengan akal sehat, perasaan dan berperilaku, serta menekankan pada perubahan yang mendalam dalam cara berpikir dan berperasaan yang berakibat pada perubahan perasaan dan perilaku (9). Rational Emotive Behavior Therapy diharapkan dapat meningkatkan kesejahteraan psikologis penderita TB Paru.

\section{Metode Penelitian}

Penelitian ini menggunakan desain penelitian quasy experiment dengan pendekatan pretest-posttest nonrandomized control group design. Populasi terjangkau dalam penelitian ini adalah semua penderita TB Paru di UPTD Puskesmas Puhjarak Kediri yang menjalani masa pengobatan kurang dari 3 bulan.

Sampel dalam penelitian ini adalah penderita TB Paru di UPTD Puskesmas Puhjarak Kediri yang memenuhi kriteria sampel, yaitu sebanyak 10 orang penderita TB Paru, sampel kemudian dibagi menjadi dua kelompok, 5 orang untuk kelompok perlakuan dan 5 orang untuk kelompok kontrol.

Teknik pengambilan sampel dalam penelitian ini menggunakan purposive sampling, yaitu teknik penetapan sampel dengan cara memilih sampel diantara populasi sesuai dengan yang dikehendaki (tujuan/masalah dalam penelitian), dengan randomisasi penempatan sampel pada kelompok perlakuan dan kelompok kontrol, sehingga sampel tersebut dapat mewakili karakteristik populasi yang telah dikenal sebelumnya.

Variabel independen dalam penelitian ini adalah kesejahteraan psikologis, dan variabel dependennya adalah Rational Emotive Behavior Therapy. Sebagai instrumen untuk pengumpulan data (pretest dan posttest) pada variabel terikat kesejahteraan psikologis adalah kuesioner kesejahteraan psikologis modifikasi dari WHOQOL-BREF domain kesejahteraan psikologis berjumlah 6 pertanyaan. Format skala sikap pada kuesioner kesejahteraan psikologis merupakan skala likert. Hasil dipersentasikan dengan menggunakan kriteria sebagai berikut: Kesejahteraan Psikologis Sangat Buruk: 0-20, Kesejahteraan Psikologis Buruk: 21-40,
Kesejahteraan Psikologis Sedang: 41-60, Kesejahteraan Psikologis Baik: 61-80, Kesejahteraan Psikologis Sangat Baik: 81100. (Anastasi \& Urbina, 1997) dalam (10). Instrumen untuk variabel bebas Rational Emotive Behavior Therapy adalah Satuan Acara Kegiatan (SAK) penelitian.

Pengambilan data awal untuk memperoleh data tentang kualitas hidup pasien TB Paru dilaksanakan pada bulan Maret 2018. Proses penelitian dilaksanakan dari bulan Maret-April 2018. Proses penelitian dilakukan setelah memperoleh ijin Direktur Akper Pamenang dan Kepala UPTD Puskesmas Puhjarak. Responden penelitian ditentukan sesuai dengan kriteria sampel dan teknik sampling. Sampel yang diperoleh dari teknik sampling adalah sebanyak 10 orang pasien TB Paru. Sampel di UPTD Puskesmas Puhjarak sebanyak 10 orang pasien TB Paru dibagi menjadi dua kelompok, yaitu kelompok perlakuan dengan responden sebesar 5 orang, dan kelompok kontrol dengan responden sebesar 5 orang. Responden yang telah terpilih akan diberikan penjelasan tentang tujuan dan manfaat penelitian. Responden kemudian diberikan penjelasan tentang petunjuk teknis perlakuan penelitian/Satuan Acara Kegiatan (SAK) sesuai dengan kelompoknya (perlakuan atau kontrol) sehingga diperoleh informed consent dari masing-masing responden.

Pretest dilakukan dengan menggunakan form kuesioner kesejahteraan psikologis adaptasi dari WHO, sehingga diperoleh skor awal sebelum intervensi. Proses pengambilan data ini dibantu oleh observer yang telah mempelajari dan memahami kegiatan penelitian. Responden pada kelompok perlakuan diberikan kegiatan penelitian berupa Rational Emotive Behavior Therapy sebanyak 4 sesi, 4x pertemuan dengan waktu 45 menit/sesi. Penilaian akhir dilaksanakan pada semua kelompok dengan menggunakan form kuesioner kesejahteraan psikologis adaptasi dari WHO kembali untuk mengetahui skor setelah intervensi. Responden pada kelompok kontrol tidak diberikan intervensi apapun, hanya melakukan tindakan keseharian masing-masing responden, tetapi setelah penelitian berakhir, kelompok kontrol juga akan diberikan Rational Emotive Behavior Therapy seperti kelompok perlakuan sebelumnya 


\section{Hasil Dan Pembahasan}

Hasil observasi tentang karakteristik responden penelitian yang meliputi jenis kelamin, usia, pendidikan, pekerjaan, status menikah, dan lama sakit akan diuraikan dibawah ini.

Tabel 1. Hasil observasi karakteristik responden penderita TB Paru di UPTD Puskesmas Puhjarak pada bulan Maret - April 2018

\begin{tabular}{|c|c|c|c|c|c|}
\hline \multirow[b]{2}{*}{ No } & \multirow[b]{2}{*}{ Karakteristik } & \multicolumn{4}{|c|}{ Penderita TB Paru } \\
\hline & & & $\begin{array}{l}\text { Kelompok } \\
\text { Kontrol }\end{array}$ & $\begin{array}{l}\text { Kelompok } \\
\text { perlakuan }\end{array}$ & \\
\hline & JenisKelamin & $\mathrm{F}$ & $\%$ & $\mathrm{~F}$ & $\%$ \\
\hline 1. & Pria & 4 & 80 & 0 & 0 \\
\hline 2. & Wanita & 1 & 20 & 5 & 100 \\
\hline & Jumlah & 5 & 100 & 5 & 100 \\
\hline & Usia & $\mathrm{F}$ & $\%$ & $\mathrm{~F}$ & $\%$ \\
\hline 1. & $<25$ & 0 & 0 & 0 & 0 \\
\hline 2. & $15-35$ & 0 & 0 & 1 & 10 \\
\hline 3. & $36-45$ & 2 & 40 & 1 & 20 \\
\hline 4. & $46-55$ & 2 & 40 & 1 & 20 \\
\hline 5. & $>55$ & 1 & 20 & 2 & 40 \\
\hline & Jumlah & 5 & 100 & 5 & 100 \\
\hline & Pendidikan & $\mathrm{F}$ & $\%$ & $\mathrm{~F}$ & $\%$ \\
\hline 1. & SD & 3 & 60 & 4 & 80 \\
\hline 2. & SMP & 1 & 20 & 1 & 20 \\
\hline 3. & SMA & 1 & 20 & 0 & 0 \\
\hline & Jumlah & 5 & 100 & 5 & 100 \\
\hline & Pekerjaan & $\mathrm{F}$ & $\%$ & $\mathrm{~F}$ & $\%$ \\
\hline 1. & Bekerja & 2 & 40 & 1 & 20 \\
\hline 2. & Tidakbekerja & 3 & 60 & 4 & 80 \\
\hline 3. & Jumlah & 5 & 100 & 5 & 100 \\
\hline & Status & $\mathrm{F}$ & $\%$ & $\mathrm{~F}$ & $\%$ \\
\hline 1. & Menikah & 2 & 40 & 4 & 80 \\
\hline 2. & Belurnmenikah & 0 & 0 & 0 & 0 \\
\hline 3. & Janda & 2 & 40 & 1 & 20 \\
\hline 4. & Duda & 1 & 20 & 0 & 0 \\
\hline & Jumlah & 5 & 100 & 5 & 100 \\
\hline & Lama Sakit & $\mathrm{F}$ & $\%$ & $\mathrm{~F}$ & $\%$ \\
\hline$\overline{1 .}$ & $<3$ bulan & 2 & 40 & 2 & 40 \\
\hline 2. & 3 bulan -1 tahun & 3 & 60 & 1 & 20 \\
\hline 3. & 1-2 tahun & 0 & 0 & 2 & 40 \\
\hline 4. & $>2$ tahun & 0 & 0 & 0 & 0 \\
\hline & Jumlah & 5 & 100 & 5 & 100 \\
\hline
\end{tabular}

Hasil observasi tentang data demografi penderita TB Paru menunjukkan bahwa jenis kelamin penderita TB Paru pada kelompok kontrol adalah pria sebanyak empat orang dan wanita sebanyak satu orang, sedangkan pada kelompok perlakuan semua responden adalah wanita.

Hasil observasi rentang usia responden pada responden penderita TB Paru pada kelompok kontrol adalah sebanyak dua responden berada pada rentang usia 36-45 tahun, sebanyak 2 orang responden berada pada rentang usia 46-55 tahun, dan sebanyak satu orang responden berada pada usia $>55$ tahun, sedangkan pada kelompok perlakuan sebanyak satu orang responden berada pada rentang usia 25-35 tahun, satu orang responden pada rentang usia 36-45 tahun, satu orang responden pada rentang usia 46-55 tahun, dan dua orang responden berusia $>55$ tahun.

Hasil observasi pendidikan responden penderita TB Paru pada kelompok kontrol sebanyak tiga orang responden berpendidikan $\mathrm{SD}$, satu orang responden berpendidikan SMP, dan satu orang responden berpendidikan SMA, sedangkan pada kelompok perlakuan sebanyak empat orang responden berpendidikan SD dan satu orang responden berpendidikan SMP.

Hasil observasi status pernikahan responden penderita TB Paru pada kelompok kontrol menunjukkan bahwa sebanyak dua orang responden berstatus menikah, dua orang 
responden berstatus janda, dan satu orang responden berstatus duda, sedangkan pada kelompok perlakuan, sebanyak empat responden berstatus menikah, dan satu orang responden berstatus janda. Hasil observasi lama sakit penderita TB Paru menunjukkan data pada penderita TB Paru lama sakit pada kelompok perlakuan adalah sebanyak dua orang responden sakit dalam kurun waktu $<3$ bulan, dan tiga orang responden sakit, dalam kurun waktu 3 bulan-1 tahun, sedangkan pada kelompok kontrol sebanyak dua orang responden sakit dalam kurun waktu $<3$ bulan, satu orang responden sakit dalam kurun waktu 3 bulan-1 tahun, dan dua orang responden sakit dalam kurun waktu 1-2 tahun. kelompok kontrol sebanyak dua orang responden sakit dalam kurunwaktu $<3$ bulan, satu orang responden sakit dalam kurun waktu 3 bulan-1 tahun, dan dua orang responden sakit dalam kurun waktu 1-2 tahun.

Hasil penilaian kesejahteraan psikologis penderita TB Paru dapat dilihat pada tabel berikut:

Tabel 2 Hasil penilaian perbedaan kesejahteraan psikologis pada penderita TB Paru kelompok perlakuan sebelum dan sesudah dilaksanakan Rational Emotive Behavior Therapy

\begin{tabular}{lcc}
\hline $\begin{array}{l}\text { Kesejahteraan } \\
\text { psikologis } \\
\text { penderita } \text { TB Paru }\end{array}$ & Domain & $\begin{array}{l}\text { Kelompok } \\
\text { perlakuan }\end{array}$ \\
& & $\begin{array}{l}\text { Pretest } \\
\text { sttest }\end{array}$ \\
\hline $\begin{array}{l}\text { Wilcoxon } \\
\text { Domain } \\
\text { rank } \\
\text { psikologis }\end{array}$ & signed & $\mathrm{p}=0.046$ \\
\hline
\end{tabular}

Hasil uji Wilcoxon signed rank test untuk mengetahui kesejahteraan psikologis pada kelompok perlakuan sebelum dilakukan Rational Emotive Behavior Therapy dan sesudah dilakukan Rational Emotive Behavior Therapy didapatkan basil p-value (nilai sig.) sebesar 0.046 dengan $\mathrm{a}<0,05$, yang berarti terdapat perbedaan kesejahteraan psikologis antara sebelum dan sesudah dilakukan Rational Emotive Behavior Therapy.

Hasil uji penilaian kesejahteraan psikologis pada kelompok perlakuan sebelum dilakukan Rational Emotive Behavior Therapy dan sesudah dilakukan
Rational Emotive Behavior Therapy menunjukkan bahwa terdapat perbedaan kesejahteraan psikologis penderita TB Paru antara sebelum dan sesudah dilakukan Rational Emotive Behavior Therapy.

Pada penderita TB Paru pengobatan dilakukan dalam jangka waktu yang lama dengan jumlah cukup dan dosis tepat selama 6-8 bulan, penderita tidak boleh putus obat dalam kurun waktu tersebut supaya semua kuman (termasuk kuman persisten) dapat dibunuh. Penderita harus ,meminum obat setiap hari dan diawasi langsung untuk mencegah terjadinya kekebalan terhadap semua OAT (11). Stigma karena mitos-mito s masyarakat terhadap penderita TB Paru juga dapat menyebabkan kesejahteraan psikologis penderita TB Paru terganggu. Teori Rational Emotive Behavior Therapy menjelaskan bahwa seseorang merasa paling bahagia ketika orang tersebut dapat mencapai tujuan hidupnya, pikiran irasional mencegah seseorang untuk mencapai tujuan tersebut, sehingga pada Rational Emotive Behavior Therapy merasionalkan pikiran tersebut untuk membantu seseorang dalam mencapai tujuan dasar tersebut (12). Eksistensial dalam terapi Rational Emotive Behavior Therapy memiliki pandangan bahwa manusia memiliki kebebasan dalam memilih, namun kebebasan tersebut bertanggung jawab. Hal tersebut memiliki anti bahwa manusia harus menerima segala resiko yang diakibatkan oleh pilihannya (12). Rational Emotive Behavior Therapy digunakan untuk meningkatkan kesejahteraan psikologis seseorang dengan mengubah keyakinan irasional menjadi keyakinan yang rasional (13). Teori Rational Emotive Behavior Therapy mengungkapkan bahwa hampir semua manusia secara sadar dan tidak sadar pada suatu tingkatan tertentu melatih dini untuk mengalami gangguan emosional, sehingga seseorang rentang mengalami gangguan psikologis dan perilaku (14). Rational Emotive Behavior Therapy terutama digunakan untuk mengatasi gangguan psikologis dan perilaku tersebut dengan menggunakan teknik berpikir, perasaan, dan tindakan yang dirancang untuk membantu mengubah perilaku 
yang merusak diri sendiri dengan cara-cara yang efektif secara sosial (14). Penelitian Yunita (15) menunjukkan bahwa penerapan teknik pendekatan Rational Emotive Behavior Therapy dapat meningkatkan kesejahteraan psikologis respondennya.

Data tersebut diatas menunjukkan bahwa Rational Emotive Behavior Therapy dapat digunakan untuk meningkatkan kesejahteraan psikologis penderita TB Paru. Responden menunjukkan respon yang baik selama proses terapi dan perubahan perilaku dan pola pikir seperti: lebih ceria, merasa percaya din, berkompetisi, memiliki perasaan mampu, berani, bahagia, tidak merasa bersalah, rendah hati, dan mandiri.

Hasil penilaian perbedaan kesejahteraan psikologis penderita TB Paru antara kelompok perlakuan dan kelompok kontrol dapat dilihat pada tabel berikut:

Tabel 3 Hasil penilaian perbedaan kesejahteraan psikologis penderita TB Paru antara kelompok perlakuan dan kelompok kontrol

\begin{tabular}{|l|l|l|l|l|}
\hline Kesejahteraan & \multicolumn{2}{|l|}{ Pretest } & \multicolumn{2}{l|}{ Postest } \\
\cline { 2 - 4 } psikologis & Kel. & Kel. & Kel. & Kel. \\
penderita TB & perla & kontrol & perla & Kontrol \\
Paru & kuan & & kuan & \\
\hline Mann whitney & \multicolumn{2}{|l|}{$=1.000$} & \multicolumn{2}{l|}{$=0.050$} \\
\hline
\end{tabular}

Hasil uji Mann whitney pada kelompok perlakuan dan kelompok kontrol pada saat pretest menunjukkan nilai $\mathrm{p}=1.000$ dengan $\mathrm{a}<0,05$, sedangkan pada saat posttest menunjukkan data $\mathrm{p}=0.050$ dengan $\mathrm{a}<0,05$, yang berarti tidak terdapat perbedaan nilai kesejahteraan psikologis penderita TB Paru antara kelompok perlakuan yang mendapatkan Rational Emotive Behavior Therapy dan kelompok kontrol yang tidak mendapatkan Rational Emotive Behavior Therapy.

Hasil penilaian pretest pada kelompok perlakuan dan kelompok kontrol menunjukkan bahwa tidak terdapat perbedaan nilai kesejahteraan psikologis penderita TB Paru antara kelompok perlakuan yang mendapatkan Rational Emotive Behavior Therapy dan kelompok kontrol yang tidak mendapatkan Rational Emotive Behavior Therapy. Hasil penilaian kesejahteraan psikologis tersebut menunjukkan bahwa diantara kelompok perlakuan dan kelompok kontrol tidak terdapat beda latar belakang diantara keduanya sebelum pelaksanaan
Rational Emotive Behavior Therapy. Pengendalian yang ketat diperlukan pada penelitian, karena kesejahteraan psikologis seseorang dapat dipengaruhi banyak hal, seperti kontrol, kesempatan yang potensial, sistem dukungan, keterampilan, kejadian dalam hidup, sumber daya, perubahan lingkungan, dan perubahan politik (Raebum dan Rootman dalam (16)).

Hasil penilaian posttest pada kelompok perlakuan dan kelompok kontrol menunjukkan bahwa perbedaan nilai kesejahteraan psikologis penderita TB Paru antara kelompok perlakuan yang mendapatkan Rational Emotive Behavior Therapy dan kelompok kontrol yang tidak mendapatkan Rational Emotive Behavior Therapy sangatlah tipis. Hasil penilaian menunjukkan kesesuaian dengan tujuan Rational Emotive Behavior Therapy, yaitu menghilangkan gangguan emosional yang dapat merusak diri (seperti benci, rasa bersalah, cemas, dan marah) serta mendidik klien agar mengahadapi kenyataan hidup secara rasional. Perbedaan hasil penilaian yang mempunyai beda yang tipis setelah dilaksanakan Rational Emotive Behavior Therapy dapat terjadi karena perbedaan data demografi responden dan pengendalian yang kurang dari peneliti. Pada kelompok perlakuan penderita TB Paru yang mempunyai perbedaan cukup besar adalah pada pendidikan dan status pekerjaan responden, dimana pada kelompok perlakuan pendidikan terbanyak adalah pendidikan SD, dan lebih banyak responden yang tidak bekerja dibandingkan dengan responden yang bekerja. Penelitian (17) menunjukkan bahwa tingkat pendidikan seseorang dapat mempengaruhi kesejahteraan psikologis, semakin tinggi tingkat pendidikan maka semakin mudah seseorang menerima informasi tentang perawatan dan pengobatan serta pasien dapat beradaptasi dengan pengobatan yang diberikan. Pekerjaan termasuk salah satu faktor yang dapat mempengaruhi kesejahteraan psikologis seseorang, seseorang yang memiliki pekerjaan mempunyai kemampuan untuk melakukan keterampilan lain yang mengakibatkan ia dapat mengembangkan dirinya (Raeburn dan Rootman dalam (16)).

\section{Simpulan Dan Saran Simpulan}


1. Hasil penilaian kesejahteraan psikologis pada kelompok perlakuan sebelum dilakukan Rational Emotive Behavior Therapy dan sesudah dilakukan

2. penderita TB Paru. Pada kelompok kontrol tidak didapatkan perbedaan nilai kesejahteraan psikologis antara pretest dan posttest.

3. Hasil penilaian pretest pada kelompok perlakuan dan kelompok kontrol menunjukkan bahwa tidak terdapat perbedaan nilai kesejahteraan psikologis penderita TB Paru antara kelompok perlakuan yang mendapatkan Rational Emotive Behavior Therapy dan kelompok kontrol yang tidak mendapatkan Rational Emotive Behavior Therapy.

\section{Saran}

1. UPTD Puskesmas Puhjarak Kediri sebagai pelaksana pelayanan kesehatan untuk penderita TB Paru diharapkan dapat menggunakan Rational Emotive Behavior Therapy sebagai cara untuk meningkatkan kesejahteraan psikologis penderita TB Paru.

2. Perawat dapat menggunakan Rational Emotive Behavior Therapy untuk meningkatkan kesejahteraan psikologis penderita TB Paru.

3. Peneliti selanjutnya diharapkan dapat melakukan penelitian kualitatif tentang kesejahteraan psikologis penderita TB Paru.

4. Penderita TB Paru dan keluarga dapat secara mandiri menggunakan Rational Emotive Behavior Therapy sebagai alternatif cara untuk meningkatkan kesejahteraan psikologis penderita $\mathrm{TB}$ Paru.

\section{Daftar Pustaka}

Christianto V, Smarandache F. What we can do to save humanity in the coming era of global eavesdroppers. Infinite Study; 2018.

Christian W, Gomes VF, Rabna P, Gustafson P, Aaby P, Lisse IM, et al. Vitamin D as Supplementary Treatment for Tuberculosis. Am J Respir Crit Care Med. 2009;179(9):843-50.

Storla DG, Yimer S, Bjune GA. A systematic review of delay in the diagnosis and treatment of tuberculosis. BMC Public Health. 2008;8(1):15.

Kesehatan K. Kesehatan dalam Kerangka Sustainable Development Goals (SDGs).

Rational Emotive Behavior
menunjukkan $\begin{aligned} & \text { Therapy } \\ & \text { bahwa }\end{aligned}$
perbedaan kesejahteraan psikologis

Rakorpop Kementrian Kesehat RI Jakarta. 2015;97:24.

WHO. WHO | Tuberculosis country profiles. Who. 2016.

Price SA, Patofisiologi WL. Konsep klinis prosesproses penyakit. Jakarta EGC. 2005;2(6):1385-9.

Guo N, Marra F, Marra CA. Measuring healthrelated quality of life in tuberculosis: a systematic review. Health Qual Life Outcomes. 2009;7(1):14.

Silvani H. Hubungan peran aktif keluarga sebagai pengawas minum obat (PMO) dengan angka kekambuhan TB paru di ruang Seruni RSUD Abdul Wahab Sjahranie Samarinda. 2016;

Hastuti S, Winkel WS. Bimbingan dan konseling di institusi pendidikan. Jakarta: Grasindo. 2006;

Nofitri N. Gambaran kualitas hidup penduduk dewasa pada lima wilayah di Jakarta. Skripsi Fak Psikol Univ Indones. 2009;

Ri K, PP\&PL D. Pedoman Nasional Pengendalian Tuberkulosis. Jakarta Kementrian Kesehat Republik Indones. 2014;

Ellis A. Using Rational Emotive Behavior Therapy techniques to cope with disability. Prof Psychol Res Pract. 1997;28(1):17.

Carson SH, Langer EJ. Mindfulness and selfacceptance. J Ration Cogn Ther. 2006;24(1):29-43.

Ellis A. Early theories and practices of rational emotive behavior therapy and how they have been augmented and revised during the last three decades. J Ration Cogn Ther. 1999;17(2):69-93.

YUNITA S. Program Kesehatan Vokal Dalam Menyanyi Berpaduan Suara Untuk Meningkatkan Kesejahteraan Psikologi. 2016;

Angriyani D. Kualitas Hidup pada Orang dengan Penyakit Lupus Erythematotus (Odapus). Skripsi Fak Psikol Universi-tas Airlangga. 2008;

S DN, Parjo, Dewi AP. Faktor-Faktor yang Mempengaruhi Kualitas Hidup Penderita HIV yang Menjalani Rawat Jalan di Care Support and Treatment (CST) Rumah Sakit Jiwa Daerah Sungai Bangkong Kota Pontianak. Univ Tanjungpuran Pontianak. 2014;

Depkes RI. Profil Kesehatan Kabupaten Kediri tahun 2015. 2015;

Dinkes Kabupaten Kediri. Profil Kesehatan Kabupaten Kediri tahun 2016;

Nursalam. Konsep dan Penerapan Metodologi Penelitian Ilmu Keperawatan. Jakarta: Salemba Medika. 2013;

World Health Organization. WHO Quality of LifeBREF (WHOQOL-BREF).2010; 
Mawaddah. Gambaran kualitas hidup pasien tuberkulosis paru yang menjalani terapi obat anti tuberkulosis di Balai Kesehatan Paru Masyarakat (BKPM) Banda Aceh. 2013; 